\title{
LAYANAN PURNA JUAL DALAM MEMBENTUK WOM (WORD OF MOUTH) PADA DAYA MOTOR CABANG PAYO SELINCAH KOTA JAMBI
}

\author{
Sylvia Kartika Wulan Bhayangkari ${ }^{1)}$ dan Fitri Widiastuti ${ }^{2)}$ \\ ${ }^{1,2)}$ Prodi Manajemen FEB Universitas Jambi, \\ Alamat e-mail: sylvia_unja@yahoo.com
}

\begin{abstract}
Abstrak.
Penelitian ini bertujuan mengetahui bagaimana pengaruh layanan purna jual dalam membentuk WOM (Word of Mouth). Penelitian ini merupakan penelitian penjelasan (explanatory research) dengan menggunakan pendekatan kuantitatif. Sampel ditetapkan sebanyak 100 responden dengan menggunakan teknik conveinience sampling dimana respondennya adalah konsumen service Daya Motor Cabang Payo Selincah Kota Jambi. Data dianalisis secara deskriptif dan kuantitatif. Analisis kuantitatif dilakukan dengan analisis regresi sederhana dengan variable layanan purna jual sebagai variable bebas dan WOM sebagai variable terikat. Hasil analisis deskriptif terhadap persepsi konsumen menunjukkan bahwa sub variable reparasi memperlihatkan performa sangat baik. Sedangkan sub variable garansi dan suku cadang terkategori baik menurut konsumen. Hasil analisis regresi memperlihatkan bahwa model regresi yang menjelaskan hubungan antara layanan purna jual dan WOM berpengaruh nyata. Dengan kata lain, layanan purna jual yang dilakukan oleh Daya Motor mendorong konsumen membentuk WOM.
\end{abstract}

Kata Kunci : Layanan Purna Jual, WOM, Konsumen.

\begin{abstract}
.
This study was aimed to find out how the influence of After Sales Service in forming WOM (Word of Mouth). It was an explanatory research with quantitative approach. One hundred sample respondents were set by using conveinience sampling technique where the respondents were consumers of Daya Motor, Branch Payo Selincah in Kota Jambi. Data were analyzed descriptively and quantitatively. Quantitative analysis was performed by simple regression analysis. Results of descriptive analysis on consumers perception showed that sub variable reparation performed very well, while two others only performed well. Based on regression analysis, a model that explained relationship between aftersales service and WOM was meaningful. In other words, after sales services performed by Daya Motor encouraged consumers to do WOM.
\end{abstract}

Key words: After Sales Service, WOM, Consumer.

\section{PENDAHULUAN}

Pemasaran tidak berhenti hanya pada transaksi penjualan. Lebih dari itu, salah satu hal yang sangat penting dan perlu diperhatikan dan merupakan suatu keharusan dalam konsep pemasaran adalah kepuasan konsumen. Sehubungan dengan itu, salah satu upaya yang harus dilakukan untuk menjamin kepuasan konsumen adalah pemberian layanan purna jual (Budi Wahyono, 2012).

Layanan purna jual adalah sebuah layanan bisnis yang mengedepankan layanan kepada konsumen setelah konsumen yang bersangkutan membeli produk atau mengadakan kerjasama dengan sebuah perusahaan produsen. Terkait hal tersebut ada beberapa aspek 
yang perlu diperhatikan seorang konsumen dalam hal layanan purna jual, di antaranya adalah garansi.

Setiap konsumen pasti menginginkan produk yang dibelinya dapat digunakan dalam jangka waktu yang relatif lama sehingga konsumen yang bersangkutan akan menghemat biaya untuk biaya perbaikan maupun pemeliharaan produk. Oleh karena itu, sistem garansi tentu sangat penting untuk menunjang keberhasilan daya jual produk di pasaran. Setiap produk tentu memiliki sistem garansi masing-masing mulai dari 1-3 tahun tergantung dari produk. Namun demikian, konsumen perlu hati-hati saat memilih sebuah produk dengan memastikan garansi yang diberikan benar-benar menguntungkan dan tidak memiliki banyak syarat yang rumit. Penyediaan garansi oleh perusahaan produsen umumnya akan didasarkan pada beberapa hal seperti:

- Ketersedian spare part

- Kerentanan penggunaan oleh konsumen

- Hitungan rasional ketahanan produk

Hal kedua yang mendukung kualitas sebuah layanan purna jual adalah kelengkapan aksesoris. Sebuah produk yang memiliki aksesoris lengkap tentu akan lebih memiliki harga jual kembali yang tinggi, sekaligus dapat digunakan dalam jangka waktu yang lama dibandingkan dengan produk tanpa kelengkapan aksesoris. Sebagai contoh, ketika seseorang membeli mobil, kelengkapan barang didalamnya seperti AC, alat pemutar video, alat keamanan, maupun pelengkap lainnya tentu akan membuat barang terlihat lebih eksklusif dan terawat dibandingkan mobil yang fitur interiornya sudah rusak. Namun demikian, untuk kelengkapan aksesoris juga ada beberapa hal yang perlu diperhatikan oleh konsumen diantaranya inovasi yang berkaitan dengan produk dan tahun produksi barang. Hal ini mengingat semakin majunya teknologi juga berpengaruh pada ketersediaan aksesoris produk yang bersangkutan.

Aspek layanan purna jual lainnya berkaitan dengan pelayanan pemeliharaan yang diberikan pada perusahaan yang membeli produk dalam jumlah besar dalam rangka mendukung proses produksi yang dilakukan perusahaan bersangkutan. Hal yang dimaksud dengan pelayanan dan pemeliharaan adalah layanan yang diberikan oleh pihak produsen dalam rangka menjaga kepercayaan konsumen untuk menggunakan produk tertentu dalam jangka waktu lama. Sebagai contoh, ada perusahaan jasa yang menawarkan jasa pembelian komputer untuk perusahaan lain dengan layanan tambahan servis yang dilakukan oleh teknisi handal dari perusahaan jasa yang bersangkutan.

Ketika konsumen membeli sebuah barang dengan harga yang relatif mahal, tentu salah satu layanan yang konsumen inginkan berhubungan dengan kecepatan tanggapan dari teknisi produk ketika terjadi masalah pada produk. Oleh karena itulah seorang konsumen perlu memperhatikan layanan yang berhubungan dengan fasilitas tambahan dimana fasilitas ini bisa digunakan setiap saat tanpa mengganggu aktivitas dari produk yang sedang Anda gunakan. Sebagai contoh, ketika konsumen membeli motor dan ada beberapa spare part dari motor yang perlu diganti maka ketersedian fasilitas tambahan dalam garansi akan mempercepat proses penanganan keluhan dan tidak mengganggu aktivitas konsumen.

Daya Motor merupakan sebuah perusahaan retail sepeda motor Honda yang sedang berkembang. Daya Motor sendiri hingga akhir tahun 2011 telah mengoperasikan lebih dari 80 cabang yang tersebar di berbagai pelosok Indonesia. Daya motor tidak hanya menjual sepeda motor saja tetapi juga melayani garansi, service dan suku cadang. Untuk di Jambi sendiri dari awal berdiri pertama kali tahun 2004 terdapat cabang resmi Daya Motor yang tersebar di berbagai kabupaten di Kota Jambi. 
Daya Motor dalam menjalankan bisnis otomotifnya selalu mengedepankan kepuasan pelanggannya. Upaya untuk mengutamakan pelanggan dilakukan dengan banyak cara salah satunya dengan selalu berusaha memberikan pelayanan terbaik dalam hal garansi, reparasi dan suku cadang yang dikemas dalam satu paket dikenal dengan istilah layanan purna jual atau after sales service. Daya Motor di setiap cabangnya melayani jualbeli sekaligus juga layanan purna jual yang mencakup penjualan suku cadang dan perbaikan kerusakan serta service berkala maupun penanganan komplain pelanggan. Untuk layanan purna jual tersebut pihak Daya Selincah mendokumentasikannya dalam laporan khusus.

Tabel 1. Jumlah Konsumen yang melakukan Service

\begin{tabular}{|c|l|r|}
\hline NO & BULAN & UNIT ENTRY \\
\hline 1 & January & 755 \\
\hline 2 & February & 827 \\
\hline 3 & Maret & 944 \\
\hline 4 & April & 854 \\
\hline 5 & Mei & 1036 \\
\hline 6 & Juni & 1073 \\
\hline 7 & Juli & 1173 \\
\hline 8 & Agustus & 808 \\
\hline 9 & September & 940 \\
\hline 10 & Oktober & 924 \\
\hline 11 & November & 960 \\
\hline 12 & Desember & 1034 \\
\hline & Total = & 11328 \\
\hline
\end{tabular}

Sumber: Daya Motor Selincah 2018

Dari data di atas terlihat bahwa selama tahun 2017, jumlah layanan purna jual perbulan berfluktuasi dengan kecenderungan meningkat. Hal tersebut mengindikasikan bahwa tingkat layanan purna jual cukup tinggi pada Daya Motor Cabang Selincah. Secara teorietis, tingginya tingkat layanan purna jual akan berpengaruh terhadap persepsi dan sikap konsumen yang akan menghasilkan Words of Mouth atau WOM. WOM yang positif akan berdampak baik bagi kelangsungan hidup perusahaan dan WOM yang negatif akan membuat perusahaan merugi karena WOM merupakan sarana efektif bagi perusahaan untuk mempertahankan pelanggan serta mendapatkan calon pelanggan.

\section{METODE}

\section{Desain Penelitian}

Penelitian ini merupakan penelitian penjelasan (explanatory research). Explanatory research merupakan penelitian yang dilakukan untuk menjelaskan hubungan kausal antara variabel-variabel penelitian melalui pengujian hipotesis (Singarimbun dan Effendi, 2012). Pendekatan penelitian yang digunakan dalam penelitian ini adalah pendekatan kuantitatif.

Pengamatan menggunakan cakupan waktu bersifat cross section/one shoot, yang berarti informasi atau data yang diperoleh adalah hasil pengumpulan data yang dilakukan pada satu waktu tertentu (Sugiyono, 2012). Populasi dalam penelitian ini adalah konsumen Daya Motor Cabang Payo Selincah yang berjumlah 11328 pada tahun 2017. Disebabkan banyaknya jumlah populasi dalam penelitian, maka disini penulis melakukan penarikan 
sampel.

Ukuran atau jumlah sampel dalam penelitian ini ditentukan berdasarkan teori yang dikembangkan oleh Slovin (Umar, 2008) dengan rumus:

Dimana:

$$
n=\frac{N}{1+N e^{2}}
$$

$\mathrm{n}=$ Ukuran sampel

$\mathrm{N}=$ Ukuran populasi

$\mathrm{e}=\%$ toleransi kesalahan sampling

$$
n=\frac{11.328}{1+\left(11.328 .10 \% \%^{2}\right)}=\frac{11.328}{114,28}=99,12
$$

Berdasarkan rumus penentuan jumlah sampel dari Slovin di atas didapat jumlah sampelnya (n) sebanyak 99,12 di bulatkan menjadi 100 dengan nilai e $=10 \%$.

Sampel dalam penelitian ini diambil dengan teknik convinience sampling, yaitu cara pengambilan sampel dari anggota populasi berdasarkan kemudahan atau menyenangkan peneliti karena data diperoleh dengan cepat caranya dengan menanyakan secara langsung kepada orang yang sedang berada di tempat objek penelitian tersebut (Ali, Hapzi dan Limakrisna, 2013). Dengan kata lain sampel. diambil/dipilih karena ada ditempat dan waktu yang tepat. Adapun kriteria konsumen yang menjadi responden dalam penelitian adalah konsumen yang minimal satu kali melakukan service ke Daya Motor Cabang Payo Selincah.

\section{Jenis dan Sumber Data}

Penelitian ini merupakan penelitian deskriptif kuantitatif sehingga data yang diperoleh adalah data kuantitatif dan akan dianalisis secara kuantitatif pula.

Berdasarkan sumber dari mana data diperoleh, data terbagi menjadi:

a. Data primer

Data primer didapatkan langsung dari sampel penelitian yaitu konsumen yang melakukan service lebih dari satu kalipada Daya Motor Cabang Payo Selincah Kota Jambi. Data primer yang diambil dalam penelitian ini meliputi variabel yang diteliti yaitu: pelayanan purna jual dan word of mouth. Operasionalisasi variable tersaji pada Tabel 2

b. Data sekunder

Data sekunder dalam penelitian ini diperoleh dari Bagian Administrasi Daya Motor Cabang Payo Selincah.

\section{Uji Validitas, Uji Reliabilitas, dan Rancangan Analisis}

Validitas suatu item pernyataan diuji dengan menggunakan korelasi "product moment". Sedangkan reliabilitas diuji dengan menggunakan Rumus Alpha Cronbach yaitu rumus yang digunakan untuk mencari reliabilitas instrument yang skornya bukan 1 dan 0 misalnya angket (kuisioner) atau soal uraian (Arikunto, 1998:192). SPSS menggunakan uji statistik Cronbach Alpha, suatu variabel diikatakan reliabel jika nilai Cronbach Alpha > 0,6.

Metode analisis deskriptif dilakukan dengan menyusun tabel frekuensi distribusi untuk mengetahui apakah tingkat perolehan skor sub variabel garansi, reparasi, dan suku cadang masuk dalam kategori: sangat baik, baik, cukup, tidak baik dan sangat tidak baik. Untuk itu dibuat kriteria pengklasifikasian yang mengacu pada ketentuan yang dikemukakan oleh Husein Umar (2008:225) dimana rentang skor diperoleh dengan rumus sebagai berikut : 
Rentang skor $=\frac{\text { Skor tertinggi }- \text { Skor terendah }}{\text { Jumlah Klasifikasi }}$

keterangan :

Skor tertinggi $=\quad$ jumlah responden $\mathrm{x}$ bobot tertinggi $\mathrm{x}$ jumlah item

Skor terendah $\quad=\quad$ jumlah responden $\mathrm{x}$ bobot terendah $\mathrm{x}$ jumlah item

Pengujian hipotesis penelitian dilakukan dengan menggunakan analisis regresi sederhana untuk mengetahui bagaimana pengaruh layanan purna $(\mathrm{X})$ jual dalam membentuk WOM (Word of Mouth) (Y) oleh Konsumen.

Model persamaan regresi sederhana:

$$
Y=\beta 0+\beta x+\varepsilon
$$

Keterangan:

$$
\begin{aligned}
& Y=\text { WOM (Word of Mouth) } \\
& \beta=\text { koefisien regresi }
\end{aligned}
$$

\begin{tabular}{|c|c|c|c|}
\hline Variabel & Definisi & Indikator & Skala \\
\hline $\begin{array}{l}\text { Layanan Purna } \\
\text { Jual }(\mathrm{X})\end{array}$ & 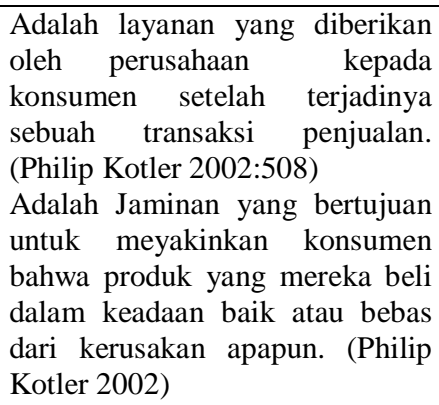 & $\begin{array}{ll}\text { - } & \text { Kualitas layanan garansi } \\
\text { - } & \text { Tingkat ketanggapan perusahaan } \\
\text { - } & \text { Kerhadap klaim garansi } \\
\text { - } & \text { Kecepuaian pemenuhan janji } \\
\text { - } & \text { Ketepatan waktu layanan Garansi }\end{array}$ & Ordinal \\
\hline Reparasi (X2) & $\begin{array}{l}\text { Adalah Pelayanan pemeliharaan } \\
\text { dan perbaikan yang dibutuhkan } \\
\text { apabila suatu produk memiliki } \\
\text { masa konsumsi yang lama dan } \\
\text { membutuhkan perawatan yang } \\
\text { teratur agar bisa selalu berfungsi } \\
\text { dengan baik,serta untuk } \\
\text { melakukan perbaikan kerusakan } \\
\text { yang terjadi pada produk tersebut } \\
\text { selama penggunaannya. (Philip } \\
\text { Kotler) }\end{array}$ & $\begin{array}{l}\text { Ketanggapan terhadap permintaan } \\
\text { perbaikan } \\
\text { - } \quad \text { Kemudahan dalam menerima layanan } \\
\text { - } \\
\text { - } \\
\text { - } \\
\text { Kecepalitan respon layanan perbaikan } \\
\text { Biaya perbaikan }\end{array}$ & Ordinal \\
\hline $\begin{array}{l}\text { Suku Cadang } \\
\text { (X2) }\end{array}$ & $\begin{array}{l}\text { Adalah ketersediaan Accessories } \\
\text { dan ketersediaan berbagai suku } \\
\text { cadang dalam layanan purna jual. } \\
\text { (Kotler Philp) }\end{array}$ & $\begin{array}{l}\text { Ketersediaan Jumlah Accessories dan } \\
\text { suku cadang } \\
\text { - } \quad \text { Kesesuaian komponen motor dengan } \\
\text { spesifikasi yang dibutuhkan } \\
\text { - Jangka waktu ketersediaan Accessories } \\
\text { dan suku cadang } \\
\text { Keterjangkauan harga Accessories dan } \\
\text { suku cadang }\end{array}$ & \\
\hline $\begin{array}{l}\text { Word of Mouth } \\
(\text { WOM) (Y) }\end{array}$ & $\begin{array}{l}\text { Adalah sebagai pembicaraan } \\
\text { yang secara alami terjadi antar } \\
\text { orang-orang, word of mouth } \\
\text { adalah pembicaran konsumen } \\
\text { asli. Sernovitz (2006) }\end{array}$ & $\begin{array}{ll}- & \text { Talkers } \\
\text { - } & \text { Topics } \\
\text { - } & \text { Volume } \\
\text { - } & \text { Dispersion }\end{array}$ & Ordinal \\
\hline
\end{tabular}

\section{Tabel 2. Operasionalisasi Variabel}




\section{HASIL DAN PEMBAHASAN}

\section{Hasil Analisis Deskriptif}

Berdasarkan data hasil penelitian, tanggapan responden/ konsumen Daya Motor terhadap sub variabel $\mathrm{X}_{1.1}$ (garansi), dan $\mathrm{X}_{1.3}$ (suku cadang) bahwa kinerja perusahaan berdasarkan sub variable tersebut berada pada kelas interval baik, bahkan sub variabel $\mathrm{X}_{1.2}$ yaitu sub variabel reparasi memperlihatkan performa sangat baik. Dengan demikian, dapat diartikan bahwa layanan purna jual perusahaan yang terdiri dari garansi, reparasi dan suku cadang merupakan faktor yang berpotensi mendorong konsumen untuk melakukan WOM ( Word of Mouth).

Dalam menyelenggarakan Layanan Purna jual, Daya Motor Cabang Payo Selincah dapat melayani dan memenuhi kebutuhan serta keinginan konsumen secara langsung dan antara konsumen dan pihak perusahaan terjadi komunikasi langsung. Dengan demikian Daya Motor Cabang Payo Selincah dapat mengetahui secara langsung keinginan para konsumen dan bagaimana mewujudkannya.

Daya Motor memberikan garansi terhadap pelayanan yang telah dilakukan secara konsisten. Perusahaan selalu berusaha untuk menjalankan komitmen dalam memenuhi garansi sesuai dengan standar pelayanan purna jual. Dalam memberikan layanan garansi pihak Daya Motor selalu mengedepankan komitmen pada daya tanggap atau respon yang cepat terhadap semua keluhan yang dilaporkan konsumen terkait dengan layanan servis yang dilakukan. Garansi yang dijanjikan di awal pembelian kendaraan selalu sama dengan garansi yang diberikan setelah pemakaian. Penanganan Garansi oleh pihak Daya Motor dilakukan dengan cepat dan sikap ramah dari karyawan tanpa konsumen harus menunggu lama. Penanganan garansi dilakukan secara tepat sesuai dengan kerusakan ataupun komplain yang dialami oleh Konsumen.

Dalam Melakukan Reparasi pihak daya Motor karyawan Daya Motor bersikap cepat tanggap dan mudah dalam melayani proses perbaikan kendaraan. Respon yang cepat ketika ada konsumen yang komplain, hasil yang berkualitas dalam melakukan reparasi, biaya reparasi yang dikeluarkan sepadan dengan hasil yang diterima konsumen serta tarif terjangkau membuat sub variabel reparasi memiliki nilai pendorong tertinggi dalam penelitian ini.

Ketersediaan aksesoris dan suku cadang dalam jumlah yang cukup pada saat dibutuhkan, kesesuaian komponen yang tersedia dengan yang dibutuhkan konsumen, pemesanan sparepart yang tidak harus menunggu lama, serta harga sparepart yang terjangkau bagi konsumen menjadi salah satu faktor yang berpotensi membentuk WOM (Word Of Mouth) pada Daya Motor Cabang Payo Selincah Kota Jambi.

\section{Layanan Purna Jual Dalam Membentuk WOM (Word of Mouth) Pada Daya Motor Cabang Payo Selincah Kota Jambi.}

Pengujian hipotesis penelitian tentang Layanan Purna Jual dalam Membentuk WOM (Word of Mouth) dilakukan dengan menggunakan salah satu perangkat uji statistik yaitu analisis regresi sederhana. Hasil analisis regresi sederhana terhadap variabel layanan purna jual dan WOM memperlihatkan nilai koefisien determinasi sebesar 0,420 atau 42,0 persen. Hal ini mengindikasikan bahwa hanya sekitar 42,0 persen variasi WOM dapat dijelaskan melalui variasi nilai variabel layanan purna jual (X), sedangkan 58\% lainnya disebabkan oleh variabel- variabel lain yang tidak dilibatkan dalam model regresi ini. Hasil analisis SPSS versi 23 yang menunjukan koefisien determinasi tersaji pada Tabel 3. 
Tabel 3. Koefisien Determinasi Model Regresi Sederhana

\begin{tabular}{|l|r|r|r|}
\hline Model & $\mathrm{R}$ & $\mathrm{R}$ Square & $\begin{array}{c}\text { Std. Error of the } \\
\text { Estimate }\end{array}$ \\
\hline 1 & $.653^{\mathrm{a}}$ & .426 & .53118 \\
\hline
\end{tabular}

Selanjutnya, analisis varians dilakukan terhadap model regresi sederhana yang dirumuskan. Hasil analisis varians memperlihatkan bahwa model regresi sederhana yang menjelaskan hubungan antara layanan purna jual dan WOM berpengaruh nyata. Dengan kata lain, bagaimana layanan purna jual mempengaruhi WOM dapat dijelaskan melalui model ini. Hasil analisis varians tersaji pada Tabel 4

Tabel 4. Hasil analisis Varians model regresi sederhana

\begin{tabular}{|l|c|c|r|c|c|}
\hline \multicolumn{7}{|c|}{ MNOVA $^{\mathbf{a}}$} \\
\hline Regression & $\begin{array}{c}\text { Sum of } \\
\text { Squares }\end{array}$ & \multicolumn{1}{c|}{ df } & $\begin{array}{c}\text { Mean } \\
\text { Square }\end{array}$ & F & Sig. \\
\cline { 2 - 6 } Residual & 20.539 & 1 & 20.54 & 72.79 & .000 \\
\cline { 2 - 6 } & 27.651 & 98 & .282 & & \\
\cline { 2 - 6 } Total & 48.190 & 99 & & & \\
\hline a. Dependent Variable: WOM \\
\hline
\end{tabular}

Untuk mengetahui pengaruh variabel layanan purna jual, dilakukan uji menggunakan uji tstudent dengan maksud menguji koefisien regresi sederhana. Hasil analisis SPSS memperlihatkan bahwa variabel layanan purna jual berpengaruh dalam membentuk WOM pada Daya Motor Cabang Payo Selincah Kota Jambi. Hasil analisis dengan bantuan SPSS tersaji pada Tabel 5 .

Tabel 5. Hasil Pengujian Koefisien Regresi Sederhana

\begin{tabular}{|l|r|r|r|r|}
\hline \multirow{2}{*}{ Model } & \multicolumn{2}{|c|}{$\begin{array}{c}\text { Unstandardized } \\
\text { Coefficients }\end{array}$} & \multirow{2}{*}{$\mathrm{t}$} & \multirow{2}{*}{ Sig. } \\
\cline { 2 - 3 } & $\mathrm{B}$ & $\begin{array}{c}\text { Std. } \\
\text { Error }\end{array}$ & & \\
\hline $\begin{array}{l}\text { (Constant) } \\
\text { LAYANAN PURNA } \\
\text { JUAL }\end{array}$ & 1.095 & .334 & 3.278 & .001 \\
\cline { 2 - 5 } & .685 & .080 & 8.532 & .000 \\
\hline
\end{tabular}

Berdasarkan Tabel 5, persamaan regresi sederhana yang dibentuk adalah : $\mathrm{Y}=0,685 \mathrm{X} 1+1,095 \quad \mathrm{R}^{2}=0,420$

Layanan purna jual dilakukan setelah berlangsungnya proses jual beli suatu produk. Garansi yang diberikan Daya Motor cabang Payo Selincah Kota Jambi berpengaruh dalam membentuk WOM (Word of Mouth) yang dilakukan oleh konsumen. Layanan garansi dikategorikan berkualitas oleh konsumen berdasarkan respon para karyawan ketika menerima keluhan dari konsumen yang akan melakukan melakukan service atau keluhan terhadap unit yang diterima. Pihak karyawan melakukan dengan cepat, tanggap dan ramah. Garansi yang dijanjikan sebelum pembelian pun sesuai dengan yang diterima setelah pembelian dan semua proses klaim garansi dilakukan dengan cepat dan tepat sesuai harapan konsumen.

Reparasi adalah layanan pemeliharaan yang dibutuhkan apabila suatu produk mempunyai masa konsumsi yang lama dan perbaikan kerusakan yang terjadi pada suatu 
produk selama masa penggunaannya (Kotler 2002). Reparasi berada pada angka tertinggi sebagai sub variabel dalam Layanan Purna Jual yang mempengaruhi konsumen melakukan WOM. Konsumen menilai bahwa petugas bagian reparasi cepat tanggap saat melayani pemeliharaan berkala ataupun saat melayani perbaikan kendaraan. Bahkan perbaikan kerusakan maupun perawatan berkala bisa dilakukan dengan mudah dimana saja termasuk mekanik bisa melakukan perbaikan di rumah konsumen tanpa harus konsumen datang terlebih dahulu ke bengkel, konsumen hanya perlu melakukan konfirmasi via telepon. Karyawan merespon dengan cepat setiap ada permintaan untuk melakukan reparasi dan konsumen menyatakan bahwa hasil reparasi yang dilakukan oleh para mekanik hasilnya berkualitas. Biaya yang dikeluarkan untuk perawatan berkala serta untuk perbaikan dianggap konsumen sudah sesuai dengan hasil yang mereka terima. Tarif yang ditentukan oleh pihak Daya Motor untuk Perawatan dan perbaikan dirasa terjangkau harganya oleh konsumen.

Ketersediaan suku cadang adalah salah satu faktor yang memegang peranan penting dalam usaha untuk memuaskan pelanggan, dimana pada akhirnya membantu mempertahankan loyalitas pelanggan (Kotler 2002). Daya motor menyediakan kecukupan suku cadang dan aksesories. Komponen aksesories dan sparepart tersedia sesuai dengan kebutuhan konsumen. Apabila suku cadang ataupun aksesories yang dibutuhkan konsumen belum tersedia maka pihak Daya Motor memesankan barang tersebut ke pusat tetapi tidak dalam waktu yang lama dengan harga yang terjangkau.

Fungsi utama layanan purna jual yaitu untuk mempertahankan pelanggan. Peranan layanan purna jual dapat menjalin sebuah hubungan antara perusahaan dengan pelanggan secara lebih baik, karena layanan purna jual adalah sebuah tanggung jawab perusahaan terhadap pelanggan atas produk yang dibeli. Daya Motor dalam melakukan layanan purna jual melalui garansi, reparasi serta suku cadang sudah mampu mendorong konsumen melakukan WOM (Word of Mouth) . WOM menjadi kekuatan yang besar bagi pihak perusahaan karena komunikasi personal dipandang sebagai sumber yang lebih dapat dipercaya atau dapat diandalkan dibandingkan dengan sumber dari komunikasi non personal menurut Zeithaml dan Bitner (2006). WOM bisa menjadi alat bagi Daya Motor untuk melakukan promosi, mendapatkan konsumen baru serta mempertahankan loyalitas pelanggan. Hal ini juga didukung dengan perbaikan ruangan khusus untuk tempat melakukan layanan purna jual yang didisain menjadi lebih luas dan menarik dengan interior dan lay out yang unik dimana konsumen yang sedang antri menunggu kendaraannya selesai direparasi bisa menyaksikan prosesnya secara langsung.

\section{SIMPULAN DAN SARAN}

\section{Simpulan}

Simpulan yang dapat ditarik dari penelitian ini adalah:

1. Kinerja layanan purna jual yang dilakukan oleh Daya Motor cabang Payo Selincah menunjukkan performa baik untuk garansi dan suku cadang serta sangat baik untuk layanan reparasi.

2. Layanan purna jual berpengaruh pada aktivitas word of mouth (WOM) yang dilakukan oleh konsumen Daya Motor Cabang Payo Selincah.

\section{Saran}

Untuk pihak Daya Motor agar dapat mempertahankan layanan purna jual khususnya layanan reparasi sedangkan untuk layanan Garansi serta Suku cadang dan spare 
part sebaiknya perlu ditingkatkan lagi.

Rendahnya koefisien determinasi mencerminkan bahwa masih banyak faktor faktor lain yang berpengaruh terhadap WOM (Word of Mouth). Oleh karena itu, untuk meningkatkan dorongan konsumen melakukan WOM seyogyanya faktor-faktor tersebut diinventarisir sehingga model dapat dielaborasi menjadi regresi berganda.

\section{UCAPAN TERIMA KASIH}

Terima kasih pada Rektor Universitas Jambi atas bantuan dana penelitian melalui Dana DIPA-PNBP Universitas Jambi Nomor SP DIPA-042.01.2.400950/2018 tanggal 05 Desember 2017, sesuai dengan Surat Perjanjian Kontrak Penelitian Kelompok PNBP Lembaga Penelitian dan Pengabdian Kepada Masyarakat Program Dosen Pemula Pada Universitas Jambi Tahun Anggaran 2018 Nomor: 2606/UN21.17/LT/2018 Tanggal 17 Mei 2018.

\section{DAFTAR PUSTAKA}

Darayani Etha Putri, Zainul Arifin, Dahlan Fanani, 2016.Jurnal Administrasi Bisnis Vol. 30.No.1.Fakultas Ilmu Komunikasi Universitas Brawijaya Malang.

Husen, Umar. 2008. Desain Penelitian Akuntansi Keperilakuan. PT Raja Grafindo Persada, Jakarta

Meriza Hedri, 2009, Pengaruh Komunikasi Pemasaran Terhadap Keputusan Pembelian Teh Kotak Ultra Rasa Melati Oleh Remaja di Kota Bandung, Jurnal.

Phillip Kotler dan Kevin Lane Keller. Manajemen Pemasaran. Jilid (Jakarta Erlangga: 2009) hlm. 5

Sartika Aprilia Fani, 2016, Pengaruh Komunikasi Pemasaran Terhadap Keputusan Pembelian Sepeda Motor Merek Yamaha V-ixion ( Studi pada P.T. Lautan Teduh Interniaga ), Skripsi.

Schiffman, Leon G dan Leslie Lazar Kanuk, 2008, Perilaku Konsumen, cetakan keempat,dialih bahasakan oleh Zoelkifli Kasip, Jakarta : P.T Macanan Jaya Cemerlang.

Singarimbun, M. \& Sofyan Effendi, 2012. Metode Penelitian Survei, Edisi Revisi, PT. Pustaka LP3ES, Jakarta

SNI 7229,2007.Ketentuan Umum Layanan Purna Jual.

Sugiono. 2009. Metode Penelitian Bisnis. Alfabeta Bandung

Sutisna, 2001, Perilaku Konsumen dan Komunikasi Pemasaran, Bandung : Penerbit P.T. Remaja Rosdakarya.

Ujang Suwarman. 2003. PKS, Teori dan Penerapannya dalam Pemasaran. Ghalia Ina, Jakarta.

Wahyono, B.2012. Pengertian, komponen, dan layanan purna jual. http://www.pendidikanekonomi.com/2012/07/pengertian-komponen-danstrategi.html. Diakses tanggal $01-04-2018$

Zeithaml, Valerie A, and mary Jo Bitner, 2006, Service Marketing, International Edition, USA : MC. Graw Hill Inc. 